\title{
Formation of Optimal Directions and Instruments for Optimization of the Development and Training System of the Organization Personnel
}

\author{
Sofia Khalitova \\ Institute of Economics and management, Department of \\ management, marketing and personnel management \\ Kursk state University \\ Kursk, Russia \\ sofia.halitova@yandex.ru
}

\section{Ludmila Afanasieva}

Institute of Economics and management, associate Professor of management, marketing and personnel management

$$
\begin{gathered}
\text { Kursk state University } \\
\text { Kursk, Russia } \\
\text { ala1909@yandex.ru }
\end{gathered}
$$

\section{Andrew Rumshin}

Institute of Economics and management, associate Professor of management, marketing and personnel management

$$
\begin{gathered}
\text { Kursk state University } \\
\text { Kursk, Russia } \\
\text { and8687@yandex.ru }
\end{gathered}
$$

\author{
Elena Postnikova \\ Institute of Economics and management, Department of \\ management, marketing and personnel management \\ Kursk state University \\ Kursk, Russia \\ postnikova.helen2015@yandex.ru
}

\section{Olga Pronskaya}

Institute of Economics and management, Professor of the Department of management, marketing and personnel management Kursk state University

Kursk, Russia

olgapronskaya@yandex.ru

\section{Alexander Afanasiev}

Institute of Economics and management, Department of management, marketing and personnel management

Kursk state University

Kursk, Russia

banned460@gmail.com

\footnotetext{
Abstract - Personnel training for the majority of Russian organizations is currently gaining special importance due to the fact that employers in the market conditions make high demands on the level of staff qualification, their knowledge and skills. Companies are aware that the training and development of personnel is an essential condition for the successful functioning of any organization, any business. Therefore, the relevance of the research is caused by the need to develop and improve the personnel training system and its staffing by using modern solutions in the field of teaching methods and techniques and staff development. The article presents the results of both a theoretical analysis of the aspects of improving the development and training system of the organization personnel, as well as the results of a systematic analysis of human resources through the example of a particular enterprise, on the basis of which optimal directions for improving the personnel management system as a whole were developed.

The result of the study is making recommendations for improving the system of development and training of the organization personnel, as well as ways to improve personnel
}

potential through the formation of a program to improve the personnel strategy.

To conduct analytical work and obtain specific conclusions in order to formulate proposals for the practical part of the work, various analysis methods were used, including abstract-logical, economic-statistical, SWOT-analysis, methods of graphical and tabular ways of presenting information.

Keywords: labor economics, personnel management, personnel training and development, human resources of the organization

\section{INTRODUCTION}

The whole system of global society is under the influence of new knowledge, new knowledge management tools, new attitudes, orientation of knowledge on the development 
- goals and objectives of training (compliance with the strategic goals of the company, the tasks of individual departments, individual development plans of employees);

- persons responsible for training (HR manager, department heads - some of them could act as internal trainers);

- areas and methods of training (according to the needs and capabilities of the company);

- calculation of the budget for training;

- drawing up a plan and schedule of training for a year;

- development of documentation regulating the learning process [5].

So, the modern system of personnel development and training should consist of a series of sequential stages characterized by independent, but interconnected goals and means of achieving them. The first stage is obtaining general educational knowledge and the formation of professional skills; the second stage is the development of special, specific knowledge and the acquisition of experience in creative activity; the third stage is periodic updating, deepening, expanding professional knowledge, skills and abilities to increase labor efficiency in accordance with the requirements of market relations and the ongoing changes in technology and production organization.

\section{LiterATURE REVIEW AND RESEARCH METHODS}

In the conditions of market relations issues related to the development and training of the organization personnel require a lot of attention since the work of the company as a whole depends on the work of its personnel.

It is also necessary to always take into account the specific facts that affect the work of the staff. All sciences and fields of learning try to be positive and deal with facts and models based on facts [10].

The theoretical and methodological basis of the study was studies of foreign and domestic economists in the field of entrepreneurship and the organization competitiveness grounded on the solution of personnel management problems. These problems were investigated in the works of such specialists as T. U. Bazarov, V. I. Gerchikov, M. M. Goikhman, V. V. Goncharov, A. P. Egorshin, B. J. Eremin, P.V. Zhuravlev, A. Y. Kibanov, M.I. Knysh, B.Z. Milner, R.A. Fathutdinov, T.V. Chirkova, S.V. Shekshnia.

The fundamental research method in this paper is analysis. Practical methodological approaches to optimizing the system of development and training of the organization personnel involve the further development and implementation of measures that contribute to the improvement of the personnel management system in the direction of personnel training.

\section{RESULTS}

Let us analyze the development and training of personnel through the example of a manufacturing enterprise in the city of Kursk. The principle of unity of command applies at this 
According to the table it is clear that the company was enterprise, the essence of which is that subordinates fulfill orders of only one leader. The management structure is based on the vertical division of managerial work and leads to management by levels. The structure selected by this company allows to make decisions quickly, match actions and ensure unity and clarity of management. The analysis of the personnel potential of the enterprise under study serves as an important organizational factor in satisfying certain social needs of both the individual and the collective, an important condition for stimulating the quality of work and especially the professional development of the individual. But the analysis of human resources can become a sphere of satisfying social needs when certain requirements are met. In this organization, all these functions are assigned to the personnel department, the purpose of which is to ensure the quality formation of human resources, participate in the creation of a stable team, and develop the competence and motivation of the staff. The staff and structure of the organization are presented in detail in table I.

TABLE I. PERSONNEL COMPOSITION AND STRUCTURE OF "KURSK NPP - SERVICE" IN THE DYNAMICS

\begin{tabular}{|l|l|l|l|l|}
\hline \multicolumn{1}{|c|}{ Indicator } & \multicolumn{1}{|c|}{$\mathbf{2 0 1 5}$} & $\mathbf{2 0 1 6}$ & $\mathbf{2 0 1 7}$ & $\mathbf{2 0 1 8}$ \\
\hline Leaders & 48 & 46 & 43 & 44 \\
\hline Specialists & 50 & 55 & 53 & 54 \\
\hline Employees & 25 & 28 & 27 & 27 \\
\hline Support staff & 388 & 400 & 391 & 401 \\
\hline Total & 511 & 529 & 514 & 526 \\
\hline
\end{tabular}

The analysis of the personnel potential of the organization showed that the number of personnel remains constant, but the category of auxiliary personnel increases due to the influence of the global economic crisis and the need for a quick response to changing market demand. The completeness of changes in the quality of staff can be tracked by the results of its movement [14].

One of the main directions of the organization's personnel policy is vocational training, retraining and advanced training of employees [6].

In the organization under study management regularly conducts work to identify the need for training and retraining of personnel for their own needs. Employees of the organization under study have the right to vocational training, retraining and advanced training, including training in new professions and specialties. The specified right is realized by making an additional contract between the employee and the employer. The staff and structure of the manufacturing enterprise allows for more detailed monitoring of quantitative changes, the data are presented in table II.

TABLE II. HUMAN COMPOSITION AND STRUCTURE OF THE INDUSTRIAL ENTERPRISE

\begin{tabular}{|l|l|l|l|l|l|}
\hline \multicolumn{1}{|c|}{ Indicator } & $\mathbf{2 0 1 5}$ & $\mathbf{2 0 1 6}$ & $\mathbf{2 0 1 7}$ & $\mathbf{2 0 1 8}$ & $\mathbf{2 0 1 9}$ \\
\hline Leaders & 38 & 48 & 46 & 43 & 44 \\
\hline Specialists & 48 & 50 & 55 & 53 & 54 \\
\hline Employees & 28 & 25 & 28 & 27 & 27 \\
\hline Support staff & 212 & 388 & 400 & 391 & 401 \\
\hline Total & 326 & 511 & 529 & 514 & 526 \\
\hline
\end{tabular}
undergoing the process of team formation during the study period, and so, in 2015, the influx of new personnel begins. The number of employees remains constant, however, the category of auxiliary personnel is increasing, due to the influence of the global economic crisis and the need to quickly respond to changes in market demand. The completeness of changes in the quality of staff can be tracked by the results of its movement.The main factor in the success of a business is a person, his skills, experience, and creative abilities. At the same time, it should be noted that a person acquires new knowledge, skills and techniques in work at the enterprise in addition to the existing education and work experience. Therefore, an indispensable condition for the relationship between an economic entity and personnel is continuous training, which is also an effective factor in motivating productive labor, since it is the level of qualification that acts as the basis for remuneration and career of each employee [7]. So, in the course of a sociological study, it turned out that more than a half of the respondents $(50 \%)$ are not satisfied to various degrees with the created opportunities for advanced training, table III. POSSIBILITY OF ADVANCED TRAINING

\begin{tabular}{|l|l|}
\hline \multicolumn{1}{|c|}{ Alternative answer } & Percentage of respondents, $\%$ \\
\hline \multicolumn{1}{|c|}{ How satisfied are you with the opportunity for continuing education? } \\
\hline 1. Completely satisfied & 26,3 \\
\hline 2. Not entirely satisfied & 24,6 \\
\hline 3. Not satisfied & 24,0 \\
\hline
\end{tabular}

Considering the above, it follows that the company needs to develop an internal company training system for its personnel that is adequate to existing economic relations, based on the needs of internal production and social activities, and which may include the following types of advanced training for employees:

- training at state educational institutions;

- training at industrial and economic seminars at the enterprise;

- internship at other enterprises, in scientific organizations and educational institutions [8].

After analyzing the internal and external environment of the company, we can identify the strengths and weaknesses, opportunities and threats (table IV).
TABLE III. THE DEGREE OF SATISFACTION OF STAFF WITH THE 
TABLE V. ASSESSMENT OF THE MISSING QUALITIES OF MANAGERS

TABLE IV. SWOT ANALYSIS OF MANAGEMENT ACTIVITIES OF THE ORGANIZATION

\begin{tabular}{|c|c|}
\hline ities & \\
\hline $\begin{array}{l}\text { 1. New technologies and the } \\
\text { ability to attract new } \\
\text { employees. } \\
\text { 2. Universities conducting } \\
\text { training in specialized areas of } \\
\text { training. } \\
3 \text {. Functioning in the } \\
\text { dynamically developing market } \\
\text { of high-tech products. }\end{array}$ & $\begin{array}{l}\text { 1. Weakening market } \\
\text { growth. } \\
\text { 2.Changing needs } \\
\text { consumers of services. } \\
\text { 3. Limited active job } \\
\text { seekers. }\end{array}$ \\
\hline Stre & Weaknesses \\
\hline $\begin{array}{l}\text { 1. Good reputation of the } \\
\text { company. } \\
\text { 2. Highly qualified staff. } \\
\text { 3. High quality control. } \\
\text { 4. Debugged communications. } \\
\text { 5. High level of competency. } \\
\text { 6. Lack of student motivation } \\
\text { to learn. }\end{array}$ & $\begin{array}{l}\text { 1. Low value of internal } \\
\text { mobility. } \\
\text { 2. The lack of a clear } \\
\text { program for the development } \\
\text { of the organization. } \\
\text { 3. Lack of career } \\
\text { development programs. } \\
\text { 4. The development system } \\
\text { in the company is based on } \\
\text { the needs of the company, } \\
\text { not staff. } \\
5 \text {. Only applied training }\end{array}$ \\
\hline
\end{tabular}

The following components were identified as opportunities for this company: the possibility of applying new technologies in order to attract new employees, the presence in the region of universities that provide training in specialized areas of training.

The following threats were identified: weakening market growth, changing needs of service consumers, limited active job seekers.

In general, the presented analysis of management activity allows us to conclude that the company has a fairly stable position in the market, however there are problems that need to be solved:

- develop a mechanism for improving the processes of personnel training in the company;

- optimize work in the field of development of the labor potential of company employees.

According to the studies, the respondents interviewed noted that managers (of all levels of the organization) lack such qualities as professional knowledge, the ability to maintain relationships with subordinates, conduct conversations with employees and listen to the opinions of employees (table V).

\begin{tabular}{|l|l|}
\hline \multicolumn{1}{|c|}{ Level of management } & \multicolumn{1}{c|}{$\begin{array}{c}\text { Percentage of } \\
\text { respondents, } \%\end{array}$} \\
\hline Director & 9,6 \\
\hline Head of Department & 8,3 \\
\hline Master & 7,2 \\
\hline Foreman & 6,9 \\
\hline \multicolumn{2}{|c|}{ Lack of ability to maintain relationships with subordinates } \\
\hline Director & 14,9 \\
\hline Head of Department & 14,2 \\
\hline Master & 9,1 \\
\hline Foreman & 12,7 \\
\hline \multicolumn{2}{|c|}{ Lack of ability to talk with employees } \\
\hline Director & 15,8 \\
\hline Head of Department & 16,1 \\
\hline Master & 9,1 \\
\hline Foreman & 10,2 \\
\hline \multicolumn{2}{|c|}{ Lack of ability to listen to the opinions of employees } \\
\hline Director & 17,4 \\
\hline Head of Department & 16,8 \\
\hline Master & 9,5 \\
\hline Foreman & 8,9 \\
\hline
\end{tabular}

An important component of leadership training should be the acquisition of knowledge in the field of psychology, since the moral and psychological climate in labor collectives is a motivating factor for effective work [15], the survey results are presented in table VI

TABLE VI. ASSESSMENT OF THE MORAL AND PSYCHOLOGICAL CLIMATE IN THE TEAM

\begin{tabular}{|l|l|}
\hline \multicolumn{1}{|c|}{ Alternative answer } & Percentage of respondents, \% \\
\hline \multicolumn{2}{|c|}{ How satisfied are you with psychological relationships in the team? } \\
\hline Completely satisfied & 43,6 \\
\hline Not entirely satisfied & 39,1 \\
\hline Not satisfied & 17,3 \\
\hline
\end{tabular}

As a sociological survey showed, more than 56\% (39.1+ 17.3) of the workers surveyed to one degree or another are not satisfied with the psychological relationships in the work collective. Today, it is necessary to reckon with the fact that human relations are not only a factor in the normal psychological climate, but also a source of growth in the professional activity of workers.

As a rule, each employee has an inherent desire to maintain work and remain in his post; desire to get a promotion or take another position; interest in raising wages; the desire to understand the ways to solve existing urgent problems of their own activities [9].

As noted above, $56 \%$ of the workers surveyed to varying degrees are not satisfied with the training opportunities created at the enterprise, and more than a third of them believe that they could perform more complex work (table VII). 
TABLE VII. THE DEGREE OF STAFF SATISFACTION WITH THE WORK PERFORMED

\begin{tabular}{|c|c|}
\hline Alternative answer & Percentage of respondents, $\%$ \\
\hline \multicolumn{2}{|c|}{ Are you satisfied with your work? } \\
\hline Not at all satisfied & 17,2 \\
\hline Partially satisfied & 55,3 \\
\hline Totally satisfied & 12,3 \\
\hline Difficult to answer & 11,8 \\
\hline \multicolumn{2}{|c|}{ Does your job match your capabilities? } \\
\hline Exactly & 43,7 \\
\hline Could be more complex & 36,2 \\
\hline Too complicated & 13,2 \\
\hline Do not know & 7,3 \\
\hline
\end{tabular}

This means employees are dissatisfied with the lack of a clearly developed system of professional growth and the change in the labor types, and this leads to the fact that the employee loses interest in the production process and is indifferent to the results of the work. If the company's management does not encourage professional growth of employees, then it may face their departure for this reason.

As a result we can say the following facts about the existing training in the organization:

- the development system in the company should be based both on the needs of the company and on the needs of the staff;

- training should be applied so as close as possible to the real practice of the student;

- training should be focused on the systematization of the knowledge of the learner;

- the student must be motivated to learn;

- acquired knowledge should be in demand.

We have developed an approximate model of the process of improving the system of development and training of personnel of a manufacturing enterprise in the city of Kursk, which is presented in figure 1 .

At the initial stage, a detailed analysis should be made. It is necessary to start with an analysis of a personnel policy. To begin with, it is necessary to give a complete description of the company's activities in order to obtain a complete picture of the activity taking into account its specifics.

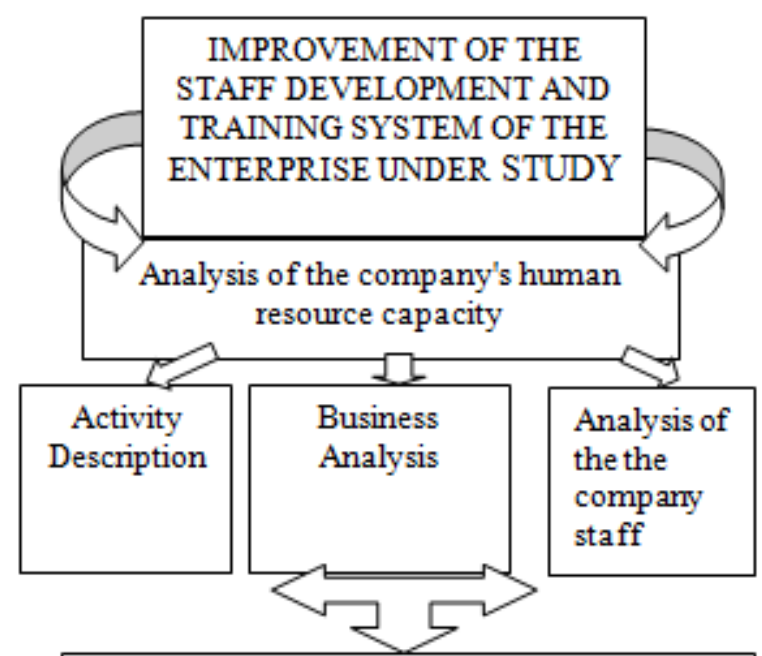

Ways to improve personnel policy

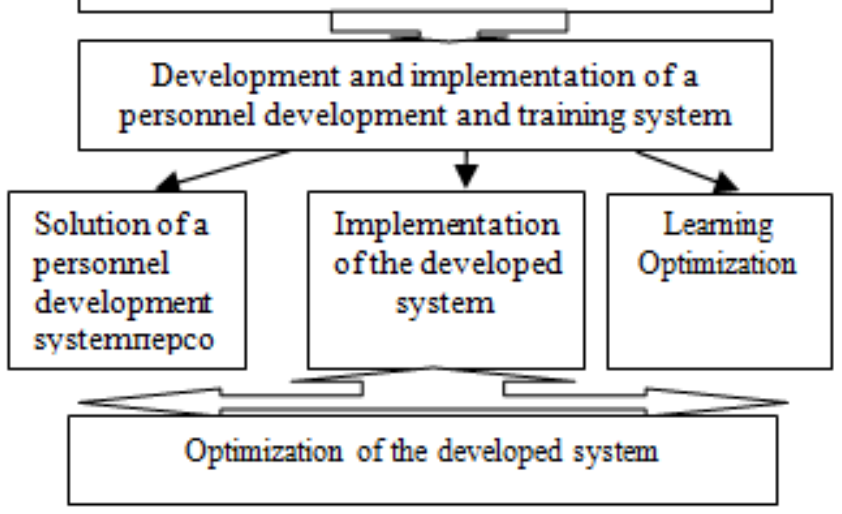

Fig. 1. Model of the process of improving the system of development and training of personnel of a manufacturing enterprise in the city of Kursk

Next, it is necessary to analyze the economic activities of the company in order to obtain a complete description of the financial stability of the company. It is also necessary to evaluate the market opportunities of the company as this is the result of the manifestation of its competitive advantages, the form and degree of realization of which determine the scale, volume, nature and success of activities in a particular market.

Next, we proposed a program of measures that allowed us to identify possible areas of staff development.

At this stage, it is necessary to conduct a study on the frequency of staff training by category, in order to identify the right category for conducting and drawing up a development plan. To do this, it is necessary for staff members to conduct a study of the internship schedule and training programs.

Then it is necessary to determine the category of workers and identify their wishes, lacking qualities. It is also necessary to conduct a sociological study to assess the moral and psychological climate in the team with the aim of learning the degree of staff satisfaction with the work performed.

The organization's recently trained staff is evaluated through interviews and questionnaires. Based on the data 
- innovative activity;

obtained, a conclusion is drawn about the quality of training for the organization's personnel. The next object for analysis is the process of forming plans for staff training, in terms of the volume of trained staff, the content of training programs and staff awareness of the processes associated with the staff training system.

Then, an analysis is carried out in the direction of evaluating the actual results of labor based on the results of training, and their impact on the adoption of personnel decisions in the organization, based on the analysis of reporting, in particular, the dynamics of labor indicators, such as production, productivity and calculation of the coefficient of training efficiency, are examined.

The following methodology can be used to conduct the analysis of the organization's personnel training system:

1. Analysis of the goals and forms of training used by the personnel of the organization, their relevance to their goals.

2. Assessment of the organization and the cost of training personnel of the organization.

3. Business assessment of the trained personnel of the organization.

4. Analysis of the collection and dissemination of information accompanying the training process of the organization's personnel.

5. Evaluation of the actual results of labor of the organization's personnel based on the results of training, and their impact on the adoption of personnel decisions [13].

Given the above, it follows that for the event under study it is necessary to develop such a system of development and training that will be adequate to existing economic relations, based on the needs of the organization's internal production and social activities, which should provide: self-education; staff rotation; retraining of workers; training workers in second (related) professions; advanced training of workers; other events.

The second category of trained workers is the functional managers and specialists of the enterprise, the professional development process of whom should be divided into three parts.

The first part is a general training program for all specialists of the enterprise and may include both general patterns of functioning of business entities in a market economy and the specifics of their activities at a regional level. Moreover, it is advisable to study all program issues using the example of your own enterprise.

It is useful to include the following questions in the overall program:

- management of organizational changes;

- $\quad$ staff motivation system;

- patent law;

- business administration;
- organizational culture, etc.

The second part of the program includes questions about the location of the training. An important role in the training system for managers (and other employees) can be played by state educational institutions, which have the necessary material resources, pedagogical staff, and can also respond relatively flexibly to the educational needs of their consumers.

Another method of training managers may be the using as teachers scientists of research institutions and higher educational institutions as they are specialists in the field of innovative technologies, psychology, as well as the heads of the regional administration and its various departments.

Training can be carried out at a particular enterprise, which will provide exchanging opinions and experience between the leaders of other enterprises, establishing business contacts with them, developing a single innovation policy together with the leadership of the region, working out a system of measures to resolve conflicts between the internal and external environment of business entities.

Such training for managers can be carried out in a variety of forms. It can be short-term seminars, conferences, round tables and the like.

The business communication between the leaders, which has a learning role, is significant here.

The third part of the training program for specialists should, in our opinion, include an individual task related to the professional activity of the employee, in other words, an individual project for the reorganization and development of the activities of the service he leads. Such a project should be publicly tested at the enterprise, feedback from colleagues should be received, and then it can be put into practice.

Teachers at this level of education are both external specialists (as a rule, scientists of higher educational institutions) invited on selected topics, as well as managers and employees of this enterprise.

For the two categories of workers mentioned above, in the current economic conditions, it is advisable to offer such a training method as job rotation, when specialists of various profiles are temporarily transferred (for a period of three to twelve months) from department to department. Rotation allows you to familiarize employees of the enterprise with many aspects of its activities, to understand the need for coordination and interconnection of departments.

The need for rotation and continuous improvement of their professional skills is explained by the characteristics of human psychology. When entering a job, a person is usually full of optimism, a new job and a new team stimulate initiative, a worker gets used to a new workplace and begins to understand his tasks competently. But, having acquired professional skills and experience, the employee feels the need for further creative development.

To restrain the desire for self-improvement is as unpromising as to carry out unplanned retraining of personnel. 
[4] E. Zavyalova., D. Kucherov, V. Tsybova. Human Resource Management at Russian Companies - Leaders of the Global Economy. Foresight and STI Governance, vol. 11, no 4, (2017) pp. 52-61.

Therefore, a manager who is interested in the professional development of employees should conduct systematic surveys to clarify their changing needs and take timely measures. An effective method of increasing the professional activity of an employee is his transfer (rotation) to a new job site. In addition, this training method does not require large financial costs.

\section{CONCLUSION}

Thus, the theoretical aspects of improving the development and training system of the organization personnel are given in the work, the essence of this system as a socio-economic category is studied.

Personnel development consists of systematic actions for choosing a strategy, planning staff requirements, managing a career, ensuring professional growth, organizing the consulting and training process, and creating an organizational culture.

One of the main directions of the personnel policy of the organization is vocational training, retraining and advanced training of employees. We also developed optimal directions for optimizing the development and training system of the organization personnel, presented ways to improve the personnel potential of the enterprise by creating a program to improve the personnel strategy, and justified management decisions about the need to change the requirements for creating an effective development and training system of the organization personnel.

\section{REFERENCES}

[1] A. Slobodskoy. Training of personnel of organizations: textbook / A.L Slobodskoy. - SPb. : Publishing House of SPbSEU, 2013 .- 124 p.

[2] T. Andersen and D. Minbaeva. Human resources in strategy development. Human Resource Management, 52 (5), 2013.PP. 809827.

[3] C. Prahalad and G. Hamel. Strategy as a field of study: Why search for a new paradigm? // Strategic Management Journal. Vol. 15 (summer special issue) 1994. PP. 5-16.
[5] L. Afanasyeva, V. Trubnikova, H. Postnikova and S. Khalitova. Identification of reserves to improve the competitiveness of the personnel management system - GCPMED 2018 International Scientific Conference "Global Challenges and Prospects of the Modern Economic Development". pp. 1687-1696.

[6] N. Latova. The human potential of Russian workers:values and attitudes. JOURNAL OF INSTITUTIONAL STUDIES. Volume 10 No. 22018 P. 44-58.

[7] E. Alpeeva, L. Afanasyeva and J. Kopteva. Innovative technologies for the preparation, adoption and practical implementation of personnel decisions. Teaching aid .- LLC "Teacher" . Kursk.- 2015.- 84p.

[8] M. Menshikova, V. Khodyrevskaya and M. Grebennikova. The role of personnel training in shaping the competitiveness of enterprises. In the collection: Innovative dominants of the social and labor sphere: economics and management. Materials of the annual international scientific-practical conference on the problems of social and labor relations (18th meeting), dedicated to the 100th anniversary of Voronezh State University. 2018. Pp. 182-185.

[9] A.Karavay. Human capital of Russian workers:state and factors // Bulletin of the Institute of Sociology, No. 17 2018, Pp. 91-112.

[10] K. Bucknall. An introduction to economics: textbook // Kevin Bucknall, publisher kevinbucknall.com. 2010 - 273 p.

[11] S. Foundation // Creative Commons Attribution-Non Commercial ShareAlike3.0, publisher Saylor.org 2014. - 155 p.

[12] C. Frey, \& M Osborne, Technology at work: The future of innovation and employment. London: Citi GPS 2015. 108p.

[13] E. Kudryavtseva, Personnel Management Capacity: Evaluation and Application Methodology. Management Consulting, 8, 2015. Pp.66-75.

[14] L. Ilyukhina. Improvement of the procedure for determining the need for training of personnel. Problems Of improving the organization of production and management of industrial enterprises. Interuniversity collection of scientific works, 1, 2015. Pp 30-36.

[15] L.Ilyukhina , V. Bogatyreva , I. Makhmudova, D. Ermakova. The corporate personnel training system development: the experience of russian enterprises - GCPMED 2018 International Scientific Conference "Global Challenges and Prospects of the Modern Economic Development". pp. 654-665.

[16] A Denisi, M.Wilson, M., \& J.Biteman. Research and Practice in HRM A Historical Perspective. Human Resource Management Review, 24(3) 2014. Pp. 219-231 